\title{
Contributions from the activity analysis to the products development project: case study based on a project of innovation and comfort in aircraft's cabins
}

\author{
Greghi, F. M.*; Rossi, N. T.; Souza, G.B.J; and Menegon, L. N. \\ Industrial Engineering Department, Federal University of São Carlos (UFSCar) - Simucad Ergo\&Ação Group \\ (www.simucad.dep.ufscar.br.) Rodovia Washington Luiz, km 235 - São Carlos, SP, Brazil - 13.565-905.
}

\begin{abstract}
Comfort is an issue that has gained relevance within the aeronautical industry due to the necessity of manufacturers and airline companies of differentiating themselves in a market that has become more and more competitive each day. This study's aim is to analyze the comfort/discomfort of passengers, based on the analysis of the activities performed in the aircrafts' cabin during real flights, in order to create ergonomics requirements and a methodology of comfort analysis. The study has been performed during domestic commercial flights, and the adopted data collection techniques have been: the application of 219 questionnaires to passengers, 44 registrations of postures and actions through filmings and 12 semistructured interviews. The method has made possible the reconstruction of the user's action course in performing activities in real flight situations, and the calculation of the area occupied by the passenger during his or her actions. The integrated analysis of the results corroborates data from previous studies in which both the space made available to each passenger and the activity performed interfere in their perception of comfort. From this study it has been concluded that the method constitutes itself as an innovative tool within the process of aircrafts' cabins project enabling the calculation of the action space based on the reconstructed course.
\end{abstract}

Keywords: ergonomics; project; activity analysis; comfort; aircraft's cabins

\section{Introduction}

Comfort is an issue that has gained relevance within the aeronautical industry due to the necessity of manufacturers and airline companies of differentiating themselves in a market that has become more and more competitive each day [8].

However, according to Vink, Looze and KuijtEvers (2005), comfort is influenced by several factors, including the physical, physiological and psychological ones, while a reaction to the environment, characterizing itself as a subjective construct individually determined.

Thus, the performed studies about the theme have pointed out some difficulties in analyzing all the variables which interfere in the perception of comfort, in a way to create comfort criteria for its application for projects of innovation in the aeronautical industry.

According to Guérin, Laville, Daniellou, Duraffourg \& Kerguelen (2001) the activity has an integrating function, once it organizes and structures the components of a situation, including individual and environmental aspects. Previous studies have cited that the activity performed by the passenger interferes in the perception of comfort [3-5-6,2]. Nevertheless, it has been verified the existence of few studies which make use of such methodology for analyzing the comfort inside the cabins within the aeronautical industry being most of those studies developed in a simulated environment $[9,1]$.

This study's aim is to analyze the comfort/discomfort of passengers, based on the analysis of the activities performed in the aircrafts'

*Corresponding author. Email: marinagreghi@dep.ufscar.br 
cabin during real flights in order to point out ergonomics requirements and a methodology of comfort analysis.

\section{Methodological formulation}

\subsection{Survey}

\subsubsection{Questionnaire design}

The first step for the elaboration of the data collection instrument has been the research in literature, followed by a previous study, carried out under the project "Comfort and Design of Aircraft Cabins", which has been developed through a partnership between Embraer and São Paulo Research Foundation (FAPESP), having the following universities USP, UFSCar and UFSC as collaborators. Besides those institutions, the National Agency of Civil Aviation (ANAC) has contributed to the research offering logistical support that enabled the data collection.

From the preparation of the research instrument to its real application, it has been tested and validated in different contexts with different group subjects, in order to ensure reliability to the data to be collected in a larger scale.

In this perspective the validation has occurred first with a sample group of students at Federal University of São Carlos (UFSCar) that had already made use of air transportation. Next, the instruments were validated together with a sample of passengers during corporate flights. Later, the validation occurred with passengers in two airports in the state of São Paulo, before large-scale application.

The survey instrument once used has been structured around the following questions:

Questions 1 and 2: they approached, respectively, some characterization aspects of the passengers and the trip (its reason, cabin class, duration, frequency and on which basis);

Question 3: level of importance of the activities performed during air trips, being 0 for minor importance and 10 for major importance;

Question 4: level of difficulty in performing the boarding/landing activities; finding the seat; placing and off-loading hand-luggage; interacting with other passengers and flight attendant(s) (requests, warnings); reading, writing and working; looking through the window; in-flight entertainment: watching films/video shows and listening to music; eating, resting and sleeping; and going to the toilet. Regarding the scale adopted by question 4 a scale in order to evaluate discomfort has been chosen. Such scale can be classified as an 11-point graphic scale classified from 0 to 10 , being 0 none discomfort at all and 10 extreme discomfort.

The data obtained from it have been statically analyzed through descriptive and multivaried, performed with the software Statistica.

\subsubsection{Sample characterization}

The sample planning of this study has been based on the information collected by the researchers together with INFRAERO, in relation to the passengers movement in 2008 , i) by aircraft type, flight timetable and destiny (37 extracts) and ii) by airports according to some regions in Brazil.

For calculating the sample size $n$, it has been initially supposed a scheme of simple random sample. Within these conditions, the simple random sample size $\mathrm{n}_{\mathrm{o}}$ of users has been determined by (Silva 1998):

$$
n_{o}=z^{2}\left[\frac{p_{0}\left(1-p_{0}\right)}{E^{2}}\right]=(2,00)^{2}\left[\frac{(0,5) \cdot(0.5)}{(0,06)^{2}}\right]=278 \cong 280
$$

Correcting the value $\mathrm{n}_{\mathrm{o}}$ to the population size $\mathrm{N}=5108$ users, it has been obtained:

$$
n=\frac{n_{0} \cdot N}{n_{o}+N}=\frac{(280)(110.661 .763)}{280+110.661 .763}=265 \cong 265 \text { users. }
$$

Supposing about $15 \%$ of non-answers, it has been added about 40 more interviews to that size of sample, which has made possible to obtain the sample final size:

$\mathrm{n}_{\mathrm{f}}=300$ users.

287 questionnaires have been applied during 40 domestic commercial flights hauls.

\subsection{Filming}

\subsubsection{Sample characterization}

46 passengers have been filmed during those 40 hauls. 11 passengers in the window seats, 31 in the aisle seats e 4 in the middle seats. The low number of passengers filmed in the middle seats has occurred due to the difficulty in finding passengers who were interested in sitting in them for the filming. All the passengers agreed with the filming.

From those, only 4 have made themselves ready for the restitution and validation of the data once collected. 


\subsubsection{Procedures for analyzing postures and actions} Concerning the data obtained through the filmings, the procedures have been taken in the following way:

a) videos organization and preparation;

b) use of a Cronoanalysis Ilios Pose 2.0, Software created by the Group Ergo\&Ação, for data analysis;

c) restitution and validation of the data with the passengers (self-confrontation methodology);

d) data analysis in a descriptive manner;

e) Reconstruction of the action courses, using the Ramsis v3.8.28 Software;

f) Creation of Postures Envelopes, using the Ramsis v3.8.28 Software and Calculation of the occupied area, using Rapdform XOR3 Software

The software has made possible for the researcher to analyze the videos and identify the postures adopted by the passengers throughout the action course, as well as the equipment and artifacts that have been used, the difficulties and successes, and atypical situations. Through this analysis it has been possible to identify the action course of each passenger, as well as to obtain quantitative analyses from the data collected during the filming.

After treating the data, some feedback on it was given to the users, making use of the selfconfrontation methodology. The aim of such selfconfrontation has been to validate the information collected through survey and interviews.

This way, it has been tried to check if the results registered by the observer corresponded to the passenger's representation concerning that flight. The number of restitutions has been low if considering the total sample, since a few participants made themselves ready to perform this stage. The restitution consisted in sending the video and analysis report to the passenger, and later discussion, over the telephone or an online chat, about the activities and events that had been observed. Such stage has enabled deep analysis of the data collected so far, as well as the identification of the main constraints and variables related to comfort.

\subsection{Interviews}

\subsubsection{Sample characterization}

There have been performed 12 semi-structured interviews with passengers during 40 domestic commercial flights hauls.
The interview script has included the following issues:

- Developed activities and frequency (duration and number of times the activity is performed during a flight cycle);

- Main difficulties and successes in performing each activity;

- Tools used in order to develop such activities;

- Detailed description of the different actions which corresponded to each activity;

- Relation between the artifacts which have been used, the space available and the environmental and also the flight conditions that can ease or burden the development of the activities;

- Atypical activities and consequences to the action.

The interviews have been recorded, with the passengers' authorization, and transcribed. For data analysis the Collective Subject Discourse analysis (DSC in Portuguese) has been used, as proposed by Lefrève; Lefrève Teixeira (2005). According to the authors, the DSC is a methodological strategy which aims to make a given social representation clearer. The statements have been organized in the following way: each one has been analyzed, extracting from it the core ideas in a way to obtain the DSC.

\section{Results}

\subsection{Survey}

\subsubsection{Sample characterization}

Survey tools have been applied to 287 users, from those 93 were females $(32,40 \%)$ and 194 were males $(67,60 \%)$.

Concerning the sample age it is possible to verify that only $5,52 \%$ was from users between 15 and 20 years old; and $3,10 \%$ of the users were 61 years old or older. A predominance of users from 21 to 60 years has been noticed. Relating to the educational level, $67,06 \%$ of the people who answered the survey have their college degree or postgraduate studies.

The main reasons cited by the users for the trips have been: businesses $(40,28 \%)$ e leisure $(19,08 \%)$.

\subsubsection{Tools and procedures}




\subsubsection{Activities and their main constraints}

From the data analysis of the questionnaires, it has been verified that the activities of eating and resting and sleeping have been performed by the interviewed passengers in a higher incidence in commercial flights. The activity considered by the passengers as the most difficult one has been resting and sleeping $(76,68 \%)$.

Table 1

Performed activities by passengers and their difficulty percentage

\begin{tabular}{|l|c|c|}
\hline \multicolumn{1}{|c|}{ Activities } & $\begin{array}{c}\text { \% of passengers who } \\
\text { perform the acitivity }\end{array}$ & $\begin{array}{c}\text { \% of passengers who } \\
\text { find some difficulty in } \\
\text { performing the activity }\end{array}$ \\
\hline Resting and Sleeping & 83,37 & 76,68 \\
\hline Eating & 91,1 & 46,06 \\
\hline Reading, writing and working & 80,58 & 42,37 \\
\hline Entertainment Activity & 56,16 & 50 \\
\hline Going to the toilet & 54,87 & 40,63 \\
\hline
\end{tabular}

The main constraints in each activity have been identified and presented as in Table 2 for the resting and sleeping activity:

Table2

Difficulties cited in the survey (by the passengers) in performing the resting and sleeping activity

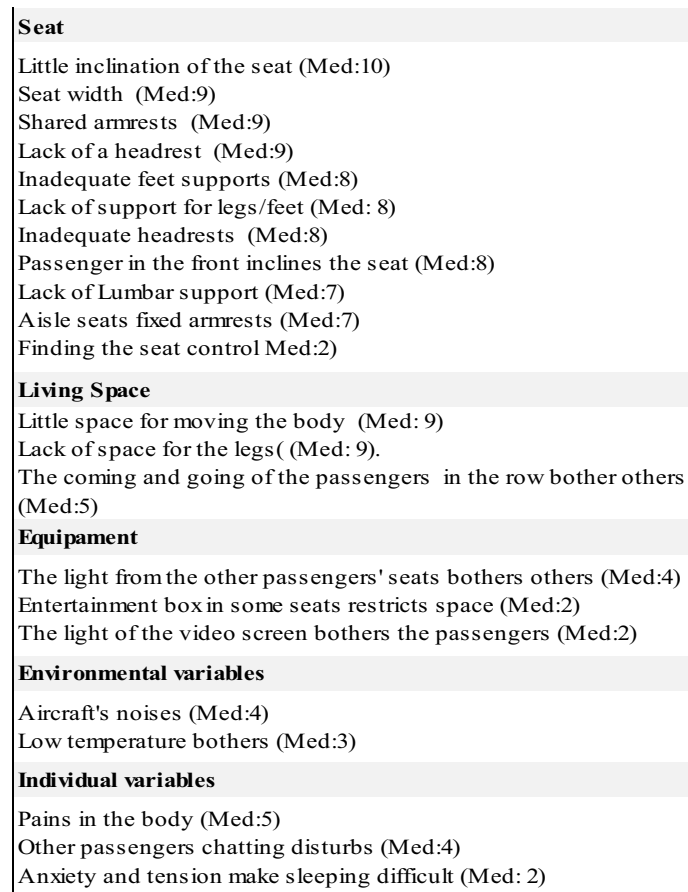

From the analysis of difficulties referring to each one of the activities, it has been noticed that the variable related to airline seats and the aircraft's aspects, such as layout, devices, cabin space etc, are the ones that cause the greatest difficulties, according to the passengers' evaluation.

The main difficulties cited have been: little inclination of the seat (Med: 10); seat width (Med: 9); shared armrests (Med: 9); lack of a headrest (Med: 9); little space for moving the body (Med: 9); lack of space for legs (Med: 9); inadequate feet supports (Med: 8); inadequate headrests (Med: 8); the passenger in the front inclines the seat, restricting the space (Med: 8).

\subsection{Interviews and restitutions}

Difficulties, eases and strategies adopted by the passengers while performing atypical activities in aircrafts cabins have been raised. Within this study the difficulties in performing the resting and sleeping activity will be exampled (TABLE 3 ).

From the analysis of the difficulties cited by the passengers in the interviews e restitutions, it has been verified that those have been similar to the ones pointed out in the questionnaires. This way, it has been verified that $38,5 \%$ of the interviewees have also pointed out as some difficulties the degree of inclination of the airline seat, and $30,8 \%$ their dimensional aspects (width, space, length).

Furthermore, difficulties related to the space occupied by the passengers have been highlighted, such as, restricted space, lack of space to move the body, the entrance and the exit of the airline seats, which interfere in the actions of going to the toilet, resting-sleeping, reading and interacting with other passengers.

It has been verified that one of the facilities cited by the passengers $(23 \%)$ has been the use of a pillow to perform the activity. Using it allows the passenger to have some support, and it replaces the headrest, nonexistent in most the aircrafts which operate in Brazilian commercial flights.

Concerning the strategies adopted by the passengers, it has been noticed that most of them look for some support (for the head/neck and legs/feet), and changing the adopted postures, in order to find "the best one" when performing the activity.

"I'm used to changing the body's position in order to find a more comfortable position (passenger). 
Table3

Difficulties cited by the interviewed passengers in performing the resting and sleeping activity

\begin{tabular}{|c|c|c|c|c|}
\hline & Diff & iculties & & \\
\hline & $\begin{array}{c}\text { Aircraft } \\
\text { space }\end{array}$ & Seat & Facilities & Strategies \\
\hline & $\begin{array}{l}15,4 \% \\
\text { Restricted } \\
\text { space }\end{array}$ & $\begin{array}{l}38,5 \% \text { Seat - } \\
\text { Degree of } \\
\text { inclination }\end{array}$ & $23 \%$ Pillow & $\begin{array}{l}\text { "If I am too tired I } \\
\text { get some sleep, } \\
\text { otherwise I only } \\
\text { take some naps } \\
\text { and wake up many } \\
\text { times" }\end{array}$ \\
\hline & $\begin{array}{l}7,7 \% \text { Narrow } \\
\text { aisle, } \\
\text { passengers run } \\
\text { into one } \\
\text { another }\end{array}$ & $30,8 \%$ Leg rests & $\begin{array}{l}7,7 \% \text { Not } \\
\text { used to } \\
\text { bringing } \\
\text { anything }\end{array}$ & $\begin{array}{l}\text { "I only get it when } \\
\text { there is a three- } \\
\text { seat row which is } \\
\text { vacant; then I use } \\
\text { it" }\end{array}$ \\
\hline 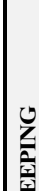 & & $30,8 \%$ Arm rests & $\begin{array}{l}7,7 \% \text { I get } \\
\text { other seats } \\
\text { when the } \\
\text { row is } \\
\text { vacant }\end{array}$ & $\begin{array}{l}\text { "It disturbs the } \\
\text { person next to you, } \\
\text { sometimes I wake } \\
\text { up almost "on" } \\
\text { him/her. It's really } \\
\text { embarrassing" }\end{array}$ \\
\hline 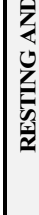 & & $\begin{array}{l}30,8 \% \text { Seat - } \\
\text { Space }\end{array}$ & $\begin{array}{l}7,7 \% \text { Music } \\
\text { helps, When } \\
\text { I linsten to } \\
\text { music, I } \\
\text { usually sleep }\end{array}$ & $\begin{array}{l}\text { "Because I like to } \\
\text { lean my head on it } \\
\text { in order to get } \\
\text { some sleep" (the } \\
\text { reason why he } \\
\text { chosen the } \\
\text { window seat) }\end{array}$ \\
\hline & & $\begin{array}{l}23 \% \text { Passenger } \\
\text { in the front } \\
\text { inclinates the seat }\end{array}$ & & $\begin{array}{l}\text { "I find the leather } \\
\text { one (seat) more } \\
\text { hygienic, everyone } \\
\text { lays on that one } \\
\text { made of fabric" }\end{array}$ \\
\hline & & $\begin{array}{l}15,4 \% \text { Seat } \\
\text { material }\end{array}$ & & \\
\hline & & $\begin{array}{l}7,7 \% \text { Espace for } \\
\text { legs and } \\
\text { shoulders }\end{array}$ & & \\
\hline & & $7,7 \%$ headrests & & \\
\hline & & $\begin{array}{l}7,7 \% \text { Disturbing } \\
\text { someone }\end{array}$ & & \\
\hline
\end{tabular}

\subsection{Action analysis}

About the records of postures and actions through filming, the main contributions of this study have consisted in the development of a method for capturing and molding activities in flight situations, aimed to producing simulations in a digital environment while making use of digital mannequins.
The method has allowed the reconstruction of the user's action course in performing activities in real flight situations, Figure 2.

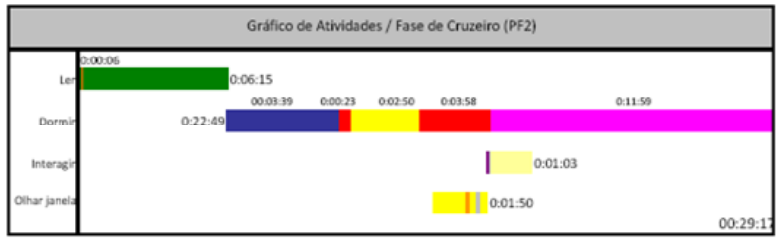

Figure 2. Example of Action Course Reconstruction

From the action course, it is possible to reconstruct the postures adopted by the passengers during the flight and to create postures envelopes (Figure 3) that use as a metric the calculation of the occupied area (frontal, back, lateral and upper view), by the passenger during the action. By the calculation of the occupied area it is possible to evaluate the aircraft's dimensions, verifying in which level they make the action possible or not.

The main difference from this simulation model to the traditional ones is that the first one allows a dynamic non-evasive analysis from the postures adopted by the passengers while performing activities within real use situations.
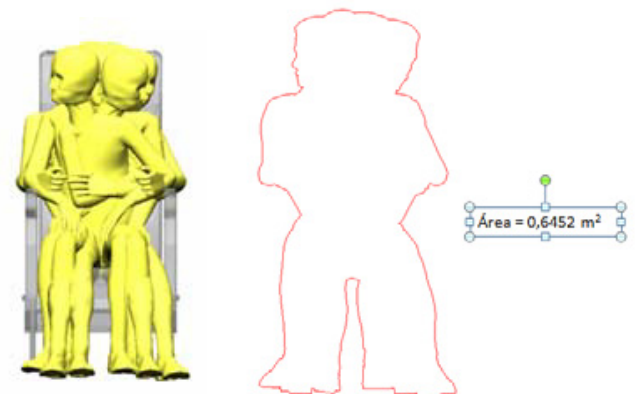

Figure 3. Example of a posture envelopes and the calculation of the area from a frontal view

\section{Discussion and conclusion}

The integrated analysis of the results corroborates data from previous studies in which the space made available for each passenger interferes in their perception of comfort. So, the method constitutes itself as an innovative tool within the process of aircrafts' cabins project enabling the calculation of 
the action space based on the reconstructed course of a real analysis situation.

Besides that, with the mentioned method it's possible to analyse the steps of action of a person in activity in an environment with occlusion and without the use of any invasive equipment. It also allows the reconstruction in digital human simulation environment of the adopted postures observed in a real time situation or a video.

From this study it is has been concluded that the activity analysis, while an approach of the ergonomics traditionally used in projects of systems conceptions or labor artifacts, can be applied to projects of products innovation in order to create some knowledge concerning the user in a real flight context.

This method can also be used in order to anticipate the human needs and the technological evolution, which demands an interaction with people in their own environment, enhancing their involvement within the production of innovations from everyday activities.

\section{References}

[1] Bertgelot, S. \& Bastien, J. M. C. (2009, juin). Apport de l'ergonomie au design de produit: application au siège d'avion. Conférence Ergodesign Forum, Lyon, França.

[2] Branton, P. (1969). Behaviour, Body Mechanics and Discomfort. Ergonomics, 12(2), 1969, 316-327.

[3] Bronkhorst, R. E., Krause, F. (2005). Designing comfortable passenger seats. In: VINK, P. Comfort and design: principles and good practice. 155-167. Florida: CRC Press.

[4] Guérin, F., Laville, A., Daniellou, F., Duraffourg, J. \& Kerguelen, A. (2001). Trabalho, tarefa e atividade. In Compreender o trabalho para transformá-lo. São Paulo, SP: Edgard Blücher.

[5] Han, S.H, Jung, E. S., Jung, M., Kwahk, J. \& Park, S. (1998). Psychophysical methods and passenger preferences of interior designs. Applied Ergonomics, 29, 499-506.

[6] Jacobson, D. I \& Martinez, A. J. (1974). The comfort and satisfaction of air travellers- basis for a descriptive model. Human Factors, 16(1), 46-55.

[7] Lefrèvre, F.; Lefrèvre, A. M. C; Teixeira, J. J.V. O discurso do sujeito coletivo: um novo enfoque em pesquisa qualitativa. Caxias do Sul: UDUCS, 2005. 256p. (Coleção Diálogos)

[8] Quehl, J. (2001). Comfort studies on aircraft interior sound and vibration. Ph.D. Dissertation, University of Oldenurg zur Erlangung des Grades.

[9] Tan, C. F., Member IAENG, Chen, W., Kimman, F \& Rauterberg, G. W. M. (2009, july). Sleeping Posture Analysis of Economy Class Aircraft Seat. Proceedings of the World Congress on Engineering, 1, 1-3, London: U.K.

[10]Vink, P., Looze, M. P. de, Kuijt-Evers, L. F. M. (2005). Theory of Comfort. In Vink, P. Comfort and design: principles and good practice. Boca Raton, FL: CRC Press. 